\title{
Improvement of the Innovative Ability for Undergraduate Students Based on the College Industrial Park
}

\author{
Guangwei Zhang \\ Industrial Department Office \\ Changchun University of Science and Technology \\ Changchun, China \\ xuemayb@163.com
}

\author{
Feng Wang \\ School of Electronic and Information Engineering \\ Changchun University of Science and Technology \\ Changchun, China \\ 770736667@qq.com
}

\begin{abstract}
To meet the innovative talents cultivation requirements of China, all kinds of cultivation methods for college students' innovation ability come out like bamboo shoots after spring rain. This paper researched the mechanism of the college industrial park and discussed its advantages to enhance the innovative ability of college students. First, the current status of college students' innovation ability is analyzed and what is hindering the innovation ability of today's college students is shown. Then, the feasibility of industrial park to improve college students' innovative ability is discussed and its advantages and practical significance is summarized. Finally, the paper discusses the development direction of the industrial park in the science and engineering universities and the promotion of college students' industrial park for undergraduates and popularization plan in the future. The paper describes the above points with the center of improvement of the innovative ability for undergraduate students based on the college industrial park.
\end{abstract}

Keywords-Industrial park; innovative ability; cultivate; science and engineering; university

\section{ANALYSIS OF CURRENT STATUS ABOUT UNDERGRADUATE INNOVATIVE ABILITY}

The cultivation of the undergraduates' innovative ability is the core goal in the university nowadays. The current status of innovative ability about undergraduate is not satisfying. There are many reasons from students, schools, families and society.

\section{A. The reasons from students}

First of all, there is a widespread blundering emotion among college students that they are eager to innovate, but lack of perseverance to innovate. Furthermore, the thoughts of undergraduates are active, but they are lack of innovative thoughts in science and engineering. They rely too much on the knowledge in textbooks, so there is a phenomenon of blind imitation study for the existing results, reference modeled more than innovation results. Third, they do not make good use of side conditions, so that it is too passive to innovate. Most college students have certain knowledge of innovation and also hope to be able to create new theories and new ideas in the study. However, they fail due to the lack of conditions or they could not make good use of the conditions around the college students.

\section{B. The reason from schools in training students}

First, colleges pay attention to knowledge but despise ability training. In colleges and universities, teaching contents are mostly is given priority with imparting knowledge and classroom teaching is still the main teaching link (Hongyi Pan, 2015). In-class hours are more and meanwhile practice is less. This way of teaching influences the development of the undergraduates' innovation ability in a large extent. Second, some unreasonable course setting limits the cultivation of students' innovative ability (Shaoning Jia, 2014). Although in recent years, many colleges and universities have increased elective courses, the heavy assignments of professional courses made students still in the scope of their professional activities, which limited the student's field of vision and influenced the cultivation of innovation ability. Popularization activities of science and technology activities organized by the school are few and the number of science and technology innovation community is small, while few undergraduates participate in the scientific research at school. Many teachers did not have the consciousness to cultivate student's practical ability. However, as we all know that only participation and practice in the scientific research and activities can improve the innovation ability of students.

\section{The reason from families}

The conservative customs seriously influence students in China, as is called conservatism. Compared to the development of innovative thinking and innovative practice, more parents tend to a successful competition of studies or a steady job for their children. They hate adventure, fear the unknown and never want their children to appear fail and setback. This ethos also brings to the child mental laziness and muddle along. Irrational spoiling will hinder the growth of children with good potential. In the nature, a cobblestone which has been endlessly rubbing and scouring by stream or torrent will be the most beautiful and hardest one. 


\section{The reason from society}

Although the schools and the education department paid great attentions to students' innovation ability and made a lot of corresponding measures to encourage and improve college students' innovative ability, it has not formed the good environment and the recognition degree of innovation ability is not enough in the whole society. Especially company and talent demand department. In order to find a satisfactory job right after graduation, students have to cater to the market demands and to learn the knowledge and skills to satisfy the present stage talents' standard. This greatly reduced the enthusiasm of students of innovation.

With the major changes of China's economy and the development of regional economic, regional innovation became the motivation of the regional economic sustainable development. We should summarize the unique culture in the field of business in the prominent place due to its regional economic characteristics, then make appropriate adjustment and upgrade between the college students' entrepreneurship and local industry development strategy and industrial structure to guide the graduates to create new industries and reach new areas (Aixia Sha,2011). It is useful to boost the competition of local industry, realize that the goal about education should serve the local economic, political development and cultural development. Under the conceptual framework of regional business, impeccable business mechanism will provide a favorable innovation environment with the interaction between enterprises, schools and society (Yeguo Qi,2010).

\section{ADVANTAGES OF COLLEGE INDUSTRY PARK}

Cooperation school with enterprise refers to the multitudinous cooperation activities between education institutions and industry in the talents' cultivation, scientific research, technical services and other fields. Industrial park is the support services platform with integrating and gathering the education resources. The college students' employment entrepreneurship is regarded as guidance, then the training focuses on ability and the vocational education is the basis. Under the circumstances, the college industrial park will be competitive with high quality skills training base and the introduction of high-quality vocational education resources. Take the college industrial park in Changchun University of Science and Technology as an example. It explores the help of industrial park to improve college students' innovative ability. As the university is close to Changchun FAW Company, some laboratories in university cooperate with FAW Volkswagen, undertake the projects in the company, then students participate together in scientific research.

\section{A. Hands-on practice and active thinking}

College industrial park provides students with a handson practice opportunity. The undergraduates can participate in the scientific research to learn advanced knowledge and think in depth. There are the projects of electronic, optical, mechanical and other aspects of the project in the industry park. College students can choose the projects according to their interests and actual situation involved. In the process of participation of the projects, they can develop innovative spirit and scientific methods.
With the cooperation of the college industrial park and high-tech enterprises, significant results can be get, which can provide a large number of opportunities to students for technical practice and social practice.

\section{B. Concentrated projects and planning management}

College industrial park's construction is different from the graduate student's laboratory. For the later one, a mentor can easily manage all the students because of small number of students. But in regular college course, there will be dozens of times of students hope to get such an opportunity to participate in the project development (Yan $\mathrm{Li}, 2010)$. If the students are assigned to the following teachers, it will certainly require a lot of teachers and greatly increase the education costs. However, the establishment of the college industrial park can solve the problem and achieve a satisfactory goal.

College industrial park makes the college students go together that have very little overlap before. A research project requires multidisciplinary knowledge and talents from different professional directions to complete together. In the division of the industry park, although there is distinction among projects, the communication between students becomes more frequent. Communion between disciplines will open a new road for college students' innovative thinking.

\section{Social contact and convenient employment}

Combining schools with industry and enterprise makes students contact with society earlier. This way not only cultivates the students' thinking and practice, but also exercises the students' ability of communication. Industrial park's construction also attracts the attention of investors and entrepreneurs and they will choose and cultivate talents, invest or provide knowledge and training. Contacting with the forefront technology of production can make students' thinking more active and improve their innovation ability. Wuhou high-tech areas of Sichuan province broaden positively employment channels and widen field with the idea of entrepreneurship creating more employment opportunities and employment promoting entrepreneurship. At the same time, Sichuan university, University of Electronic Science and Technology, Chengtu Information Engineering Institute and other well-known colleges and universities built a college league pioneer park, to issue demanded talents letter or hold job fairs to the universities. Outstanding graduate colleges and universities can be recommended to the enterprise employment.

\section{Connecting with universities}

Science and technology industrial parks with the advantages of scientific research in the school combine the comprehensive intellectual resources of the university with the others social advantage resources. Then the industrial park provides a supporting platform on transformation of scientific and technological achievements, hi-tech enterprises incubation, innovative talent training and industry-university-research cooperation. In the meantime, it attracts a large number of high-level personnel to campus to start a business for a competitive partner. A large number of personnel are intramural experts and professors and these experts and professors have profound academic knowledge and a wealth of experience, self- 
employment and practice. College students will have a big harvest in intelligence when they can communicate with the experts.

\section{DEVELOPMENT FOR COLLEGE INDUSTRY PARKS}

College industrial park is a market-oriented comprehensive industrial base combining innovative research and development, production, information exchange and exhibition. A college industrial park only needs the school investment a 1000 square meters construction area for a decorated park and introduces partnerships for project operation together. So it can achieve the development and value of the industrial park. The developing direction should have the following several aspects.

\section{A. Sufficient resources}

Industrial parks should proceed with the entrepreneurial activity based on the advantage subjects of the college. Industrial parks should expand and deepen the universities subject field of study and make professional universities keeping up with leading edge developments in industry and social through the connection between professional university and industry. Naturally, there exist conditions for the innovation of thinking for students. At the same time, the advantage of government and social resources should be actively make good use of to provide attractive policy and guarantee for the park. Companies can provide the best service and most advanced management experience of the park. Schools should make full use of existing resources to support on policy and material and they may appoint a certain number of teachers to the park project teams as technical guidance. Each group had better have one or two teachers.

\section{B. Experts' guidance}

The industrial park will attract many entrepreneurs and investors because of the close relationship between enterprises and industrial parks. All the experts may be the investors in industrial park to build their own laboratories, studios, and research centers. With the help of advanced and cutting-edge technology, it will improve the innovative thinking of the college students in industrial park. The development of college students' field of vision can exercise their ability and lay a good foundation for their graduate employment.

\section{Industry-related mode}

Industrial parks cannot abandon other relatively weak disciplines while it is based on the advantage disciplines. In Changchun University of Science and Technology, the introduced project types should have clear rules. The project should conform to the following types, such as electronic information, photoelectric information, science and technology innovation, design and engineering supervision. In the aspect of content, it requires stronger maneuverability, innovative and technology content, which will insure university students not to be pedantic when researching the science and technology. Driving the other projects at the time will fully develop main advantage disciplines. Innovation is not only in science and technology aspect, but also in cultivating college students' cultural innovation, thought innovating, which needs the promotion of other disciplines, such as culture, entertainment and media. With the industrial park development, it will bring new talent demands that management personnel, technical personnel, communication talents are needed by society and their innovation ability is a standard determining factor whether they can cater to the needs of the society or not.

\section{Student-centered thoughts}

This aspect requires the difficulty degree of the industrial park depended on the actual situation of students to exercise students' skills. They cannot blindly select the project and don't covet interests to choose a one that isn't actual. With the development of the society, the progress of science and technology and the deepening reform of higher education, science and technology of university are strengthening. We should encourage students to put technology into direct productive forces and achieve technology transfer and achievements transformation in the college industrial park. In the meantime, colleges and universities should also give the full advantages of talents, technology and resources to help students to improve the independent innovation ability. Then it can radiate the school surrounding. Students should communicate with enterprises according to their own requirements to achieve self-selection on contacting the project cooperation.

The establishing of industrial park for college students has provided a new way for improving college students' innovation ability. It not only exercises the students' innovation ability, but also increases their practice ability. The figure below shows the specific operation of the industrial park.

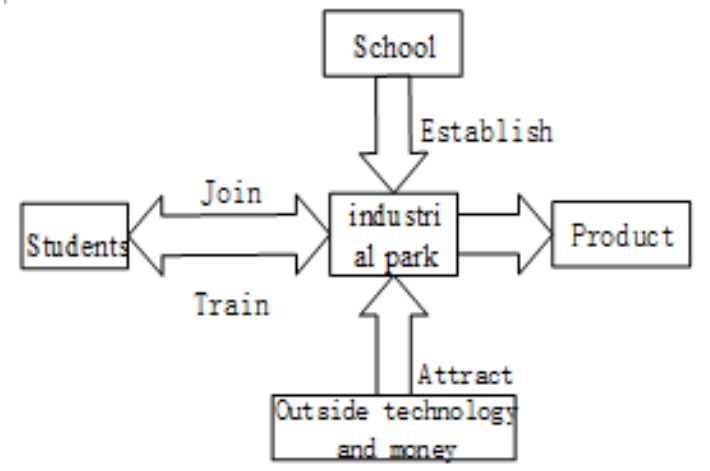

Figure 1. The relationship in industrial park

\section{CONCLUSIONS}

The philosophy of industrial park is originated from popular laboratory graduate student. On the basis of small laboratories, the college industrial park is developed though integrating resources and technology. This industry can not only obtain good benefits and quick effect, but also link reality with network. There is no pressure of fund or worries of staffs. If necessary, it can provide the cost of living subsidies for college students. Therefore, it is an effective way to solve employment problem of colleges and universities for a long time.

In terms of students' innovative thinking, the industrial park is a miniature exemplary role. The industrial park has achieved gratifying results. Through hands-on practice, students will have a positive thinking when suffering 
difficulties, exercising the ability to think and adopting new methods to solve new topic. This is obviously different from the traditional cultivating ways of college students.

\section{REFERENCES}

[1] G. Eason, B. Noble, and I. N. Sneddon, "On certain integrals of Lipschitz-Hankel type involving products of Bessel functions," Phil. Trans. Roy. Soc. London, vol. A247, pp. 529-551, April 1955 (references)

[2] J. Clerk Maxwell, A Treatise on Electricity and Magnetism, 3rd ed., vol. 2. Oxford: Clarendon, 1892, pp.68-73.

[3] I. S. Jacobs and C. P. Bean, "Fine particles, thin films and exchange anisotropy," in Magnetism, vol. III, G. T. Rado and H. Suhl, Eds. New York: Academic, 1963, pp. 271-350.

[4] K. Elissa, "Title of paper if known," unpublished.
[5] R. Nicole, "Title of paper with only first word capitalized," J. Name Stand. Abbrev., in press.

[6] Y. Yorozu, M. Hirano, K. Oka, and Y. Tagawa, "Electron spectroscopy studies on magneto-optical media and plastic substrate interface," IEEE Transl. J. Magn. Japan, vol. 2, pp. 740 741, August 1987 [Digests 9th Annual Conf. Magnetics Japan, p. 301, 1982].

[7] M. Young, The Technical Writer's Handbook. Mill Valley, CA: University Science, 1989.

[8] Electronic Publication: Digital Object Identifiers (DOIs):

[9] D. Kornack and P. Rakic, "Cell Proliferation without Neurogenesis in Adult Primate Neocortex," Science, vol. 294, Dec. 2001, pp. 2127-2130, doi:10.1126/science.1065467.

[10] H. Goto, Y. Hasegawa, and M. Tanaka, "Efficient Scheduling Focusing on the Duality of MPL Representatives," Proc. IEEE Symp. Computational Intelligence in Scheduling (SCIS 07), IEEE Press, Dec. 2007, pp. 57-64, doi:10.1109/SCIS.2007.357670. 